\title{
Evaluation of Prequalification Decision Criteria for Selecting Contractors in Nigeria using Analytic Hierarchy Process
}

\author{
A. H. Afolayan \\ Department of Computer Science \\ Federal University of Technology, \\ Akure, Nigeria
}

\author{
B. A. Ojokoh \\ Department of Computer Science \\ Federal University of Technology, \\ Akure, Nigeria
}

\author{
S. A. Adeyinka \\ Department of Computer Science \\ Federal University of Technology, \\ Akure, Nigeria
}

\begin{abstract}
In recent years, contractors play a major role in construction projects of buildings, roads, or waterworks under supervision of project owners or employers of these projects. Selecting the most suitable contractor for a construction project is a crucial decision for owners and project managers alike. Ranking the candidate contractors has become a key challenge for firms and enterprises. The study identified and assessed the existing contractors' decision criteria and then rank the decision criteria used for selecting contractor in Federal Universities in Nigeria with the aim of providing information that could enhance contractor's selection in construction project. Data were collected with the aid of structured questionnaires. 60 questionnaires were distributed to construction professionals/ staff of which 55 responses were returned and 50 used for analysis. Information gathered includes the major contractors' prequalification criteria. The collected data were analyzed and rank in order of priority using the AHP interface in Microsoft Excel. The results showed that Technical capability of contractors ranked the most important of the existing prequalification criterion followed by Management capability among others. The study concluded that past performance of contractors was the most important existing criterion for contractor pre-qualification in the study area among others while the most determinant factor in the choice of these criteria was contractor's resources, which must be considered in the selection of contractors.
\end{abstract}

\section{Keywords}

Construction projects, contractors, Analytic Hierarchy Process, prequalification criteria.

\section{INTRODUCTION}

The successful execution of construction projects and keeping within estimated cost and schedules depend on a right prequalification that requires sound contractor selection [1]. Many construction projects experience time and cost overruns due to wrong choice of contractors. This challenge is more evident in the government contract in which contracts are awarded to the lowest bidder not responsive bidder as they fulfilled prequalification criteria requirement - the awarding strategy of the majority of public project in developing countries including Nigeria.

Evaluation of the most eligible contractors is important for project performance and success in construction projects. Contractor selection (CS) is a process which involves investigating, screening and determining whether candidate contractors have the technical and financial capability to be accepted to formally tender for construction work. The selection process should identify a contractor to whom the client can confidently entrust the responsibility to execute the project satisfactorily, but unfortunately this is not always possible. An incapable contractor causes all kinds of problems such as delays, cost overruns, inappropriate work, disputes, or other major issues.

Decision Criteria are those variables or characteristics that are important to the organization making the decision. They should help evaluate the alternatives from which you are choosing. When people make decisions, they base their choice on a number of factors, some logical and some personal. Sometimes this is deliberately done, with careful consideration of the criteria used, but often (and even in 'logical' situations), some other factors are subconsciously taking into consideration. [2] stated that the challenge for decision-maker is finding the best way of measuring and assessing the contractors' capabilities.

Analytic Hierarchy Process (AHP), is an effective tool for dealing with complex decision making, and may aid the decision maker to set priorities and make the best decision [3]. It uses informed judgment or expert opinion to measure the relative value or contribution of these attributes and synthesize a solution. It is a systematic decision making method which includes both qualitative and quantitative techniques. It is being widely used in many fields for a long time. Basically AHP is a method of breaking down a complex, unstructured situation into its components parts; arranging these parts, or variables, into a hierarchic order; synthesize the judgments to determine which variables have the highest priority and should be acted upon to influence the outcome of the situation.

In Nigeria, the process of contractor selection for the public projects is regulated by [4]. Despite introducing a point system to evaluate both the technical and financial offers, the Act still has some disadvantages. First, it did not mandate the use of the point system for contractors' evaluation. Second, it did not provide project managers and professionals with any criteria that could be taken into consideration for evaluating contractors' bids both technically and financially. Third, it only focuses on the bid price in evaluating financial offers [5].

The significance of this study is to provide baseline information to the construction clients and consultants in the Federal Universities in Nigeria, on the importance of contractor's prequalification selection criteria to be adopted, which will eventually translate to a better decision making and increase project performance. The objectives of this research are as follows: 
(i) review the various criteria used for contractors prequalification and bid evaluation as stated in the literature.

(ii) identify the criteria that are actually used to evaluate contractors' pre-qualification and bids in Nigeria.

(iii) evaluate and analyze the relevant criteria for contractor's selection in Nigeria.

(iv) rank the criteria in order of priority using Analytic Hierarchy Process.

\section{LITERATURE REVIEW}

Contractor pre-qualification and bid evaluation procedures are currently used in many countries, and involve the development and consideration of a wide range of decision criteria to evaluate the overall suitability of contractors. A literature review on the decision criteria used in selecting contractors suggested a combined list of criteria used by clients when choosing main contractor ([6]; [7]; [8]; [9]; [10]; and [11]) as shown in Table 1.

Table 1. Decision criteria for selecting main contractor from literature review

\begin{tabular}{|c|c|c|c|c|c|c|}
\hline \multirow[b]{2}{*}{$\begin{array}{l}\text { Main Contractor } \\
\text { Selection Criteria }\end{array}$} & \multicolumn{6}{|c|}{ Previous Study } \\
\hline & $\begin{array}{l}\text { Puri and } \\
\text { Tiwari } \\
(2014)\end{array}$ & $\begin{array}{l}\text { Nieto-Morote, } \\
\text { and Ruz-Vila } \\
\text { (2012) }\end{array}$ & $\begin{array}{l}\text { Arazi et al., } \\
\text { (2011) }\end{array}$ & $\begin{array}{l}\text { Topcu } \\
\text { (2004) }\end{array}$ & $\begin{array}{l}\text { Palaneeswarn and } \\
\text { Kumarasway, } \\
\text { (2001) }\end{array}$ & $\begin{array}{l}\text { Skitmore, } \\
\text { (1999) }\end{array}$ \\
\hline Financial stability & $\sqrt{ }$ & $\sqrt{ }$ & $\sqrt{ }$ & $\sqrt{ }$ & $\sqrt{ }$ & $\sqrt{ }$ \\
\hline Background of company & & & & $\sqrt{ }$ & $\sqrt{ }$ & $\sqrt{ }$ \\
\hline Technical capacity & $\sqrt{ }$ & $\sqrt{ }$ & $\sqrt{ }$ & & $\sqrt{ }$ & $\sqrt{ }$ \\
\hline Cost & & & & $\sqrt{ }$ & $\sqrt{ }$ & $\sqrt{ }$ \\
\hline Past Performance & & $\sqrt{ }$ & $\sqrt{ }$ & $\sqrt{ }$ & & \\
\hline Standard of quality & & & & $\sqrt{ }$ & $\sqrt{ }$ & $\sqrt{ }$ \\
\hline Occupational health and safety & $\sqrt{ }$ & $\sqrt{ }$ & $\sqrt{ }$ & $\sqrt{ }$ & $\sqrt{ }$ & $\sqrt{ }$ \\
\hline Time performance & & & $\sqrt{ }$ & $\sqrt{ }$ & $\sqrt{ }$ & $\sqrt{ }$ \\
\hline Management capability & $\sqrt{ }$ & $\sqrt{ }$ & $\sqrt{ }$ & $\sqrt{ }$ & & \\
\hline Failed contract & & & & $\sqrt{ }$ & & \\
\hline Progress of work & & & & $\sqrt{ }$ & & \\
\hline Human resource management & & & & & & $\sqrt{ }$ \\
\hline Level of technology & & & $\sqrt{ }$ & $\sqrt{ }$ & & \\
\hline Relationship with client & & & $\sqrt{ }$ & & $\sqrt{ }$ & $\sqrt{ }$ \\
\hline Relationship with sub-contractors & & & & $\sqrt{ }$ & & \\
\hline Fraudulent activity & & & & $\sqrt{ }$ & & \\
\hline Competitiveness & & & & $\sqrt{ }$ & & \\
\hline Reputation & $\sqrt{ }$ & & & & & \\
\hline Bid Price & & & $\sqrt{ }$ & & & \\
\hline Political Considerations & & & $\sqrt{ }$ & & & \\
\hline Friendship & & & $\sqrt{ }$ & & & \\
\hline Experience in similar projects & & $\sqrt{ }$ & $\sqrt{ }$ & & & \\
\hline Progress of existing projects & & & $\sqrt{ }$ & & & \\
\hline No of projects at hand & & & $\sqrt{ }$ & & & \\
\hline
\end{tabular}

Several researches have been carried out by different researchers on decision criteria. [12] ranked the main criteria for contractor selection procedures on major construction projects in Libya using the Delphi Method. This paper evaluates the current state of knowledge in relation to contractor selection process and demonstrates the findings from the analysis of the data collected from the Delphi questionnaire survey. The survey was conducted with a group of 12 experts working in the Libyan construction industry (LCI). The paper aims to rank contractor selection criteria with specific application to make construction projects in the Libyan context.

[11] evaluated the criteria for contractors' selection and bid evaluation. This study identified the criteria for selection of 
contractor and bid evaluation with different emphases to suit the requirements of clients and projects. The methodology used in this research was conducted by sending a questionnaire to different project managers in India and had an exceptionally high rate of response of $72 \%$. The analysis led to some interesting findings that reflect on the current practice. The paper also provide construction contractors with recommendations in pursuit of better evaluation of construction bids both technically and financially.

[13] investigated the criteria for contractors' selection and bid evaluation in Egypt. The paper aim at reviewing the various criteria used for contractors pre-qualification and bid evaluation, identifying the criteria that are actually used to evaluate contractors' pre-qualification and bids in Egypt, and also introducing some recommendations for enhancing the contractors' selection process in Egypt.

In Nigeria, several researchers have carried out researches on contractor's selection. [2] studied process for selecting contractors for construction works in Nigeria. The study only revealed a strong relationship between contractor performance of construction projects and technical capability. Also, [14] observed that in Nigeria, selection of contractors for construction projects is largely subjective.

[15] investigated the impact of contractors prequalification on construction project delivery in Nigeria. The research discovered success in construction project delivery performance in terms of time and quality in the adoption of due process, not minding cost of the project.

[16] stated that current selection methods are faced with inherent weaknesses which adversely affect the performance of the construction project. This call for an intuitive study, to establish the important criteria to be given at most consideration in assessing contractors and selection of contractors in public sector in Nigeria.

[17] examined the determinant factors for the choice of the prequalification criteria in Niger Delta region of Nigeria with the aim of providing information that could enhance contractor's selection in a recessed economy. Questionnaires were administered on the entire population, out of which 77 were retrieved and used for analysis. The collected data were analyzed using, Mean Item Score (MIS) and Factor Analysis (FA). The results showed that past performance of contractors ranked the most important of the existing pre-qualification criterion followed by experience of the contractor and evidence of incorporation.

Therefore the overall motivation of this research is the need to analyze, evaluate and rank decision criteria for contractor selection in Federal Universities in Nigeria. The research will provide baseline information to the construction clients and consultants on the importance of contractor's prequalification selection criteria to be adopted, which will eventually translate to a better decision making and increase project performance.

\section{RESEARCH METHODOLOGY}

An extensive review of some existing literature in the area of decision criteria and Analytic Hierarchy process were carried out. In this research, Federal Universities in Nigeria were chosen as a case study. A general literature review was carried out on different criteria that are used by Federal Universities in Nigeria when awarding a contract to contractors. In this research, [3] model was adopted. These are; structuring the hierarchy, pair-wise comparisons (determining the weights) and ranking phase (ranking of the decision criteria). Figure 1 shows the flowchart of the AHP Process.

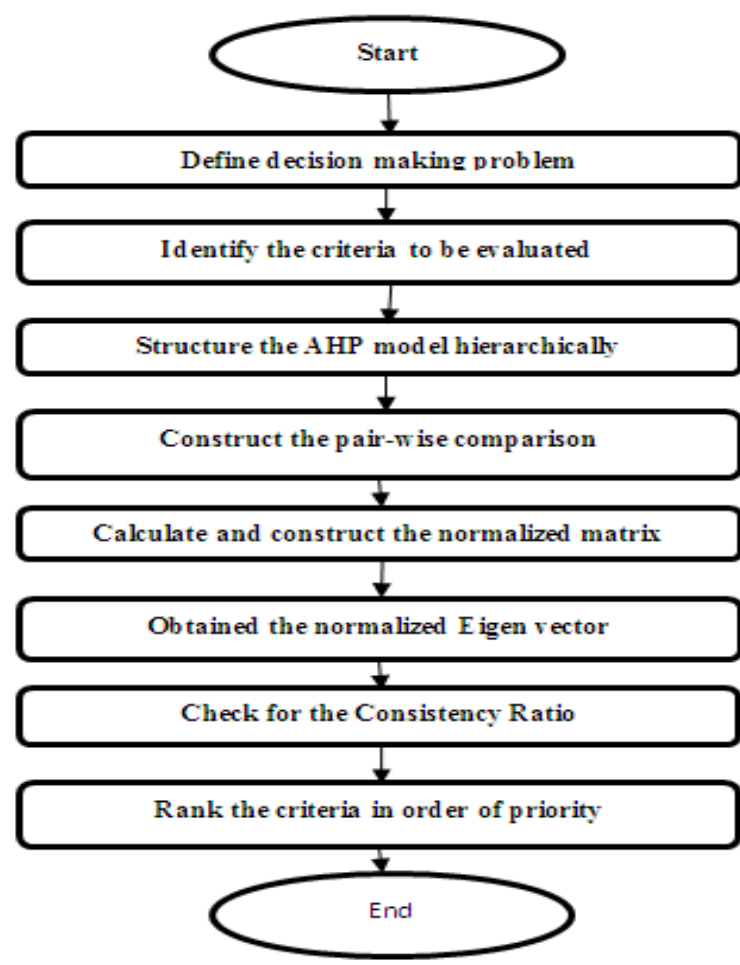

Figure 1: flowchart showing the process of AHP

Step 1: Define the decision making problem

The decision making problem is ranking the decision criteria used in contractor selection using Federal Universities in Nigeria as a case study.

\section{Step 2: Identify and state all the criteria involve in the selection process.}

Decision makers play an important role on the reliability and accuracy of solving contractor selection problems, because the problem of ranking the decision criteria using AHP is modeled on decision maker's judgment. This research first identified the actual criteria from literature review and criteria used by clients for the selection of contractors from current practice in Nigeria. This was investigated through a questionnaire which covers a selected sample of 60 . The respondents were allowed to add other criteria not covered by the questionnaire. The ranking were based on the relative importance of the criteria as perceived by professionals operating in the procurement units (procurement officers) and some other professionals that were involved in the decision making process using their accumulated experience and judgment.

The criteria used in this research were adopted from the research of [11] and [10].Table 2 consists of the main criteria that were considered; the criteria are: Financial Stability, Technical Capability, Past Performance, Occupational Health and Safety, Management Capability, Reputation, Experience in similar project. 
Table 2. Main Technical Criteria to be evaluated

\begin{tabular}{|l|l|l|}
\hline S/N & Criterion & Main Contractor Selection Criteria \\
\hline $\mathbf{1}$ & $\mathbf{C}_{\mathbf{1}}$ & Financial Stability \\
\hline $\mathbf{2}$ & $\mathbf{C}_{\mathbf{2}}$ & Technical Capability \\
\hline $\mathbf{3}$ & $\mathbf{C}_{\mathbf{3}}$ & Past Performance \\
\hline $\mathbf{4}$ & $\mathbf{C}_{\mathbf{4}}$ & Occupational Health and Safety \\
\hline $\mathbf{5}$ & $\mathbf{C}_{\mathbf{5}}$ & Management Capability \\
\hline $\mathbf{6}$ & $\mathbf{C}_{\mathbf{6}}$ & Reputation \\
\hline $\mathbf{7}$ & $\mathbf{C}_{\mathbf{7}}$ & Experience in similar project \\
\hline
\end{tabular}

$\mathbf{C}_{1}$ : Financial Stability: This indicator category signifies the financial credibility of a contractor with which it can handle capital crises ([18]; [19]). The client must reach an informed opinion regarding the overall financial position and ability of contractor [10].

$\mathrm{C}_{2}$ : Technical Capability: In this factor, the contractor must prove that it has the technical capacity to perform all activities required by a specific project [19]. To provide a consistently high quality product or service, promote successful development efforts, and ensure future improvements, a firm needs competent technical support from its contractors.

$\mathbf{C}_{3}$ : Past Performance: Past performance of a contractor is the measure of the body of similar work done satisfactorily by a contractor in the past [20] resulting in a higher or lower degree of confidence in the possible contractors regarding the quality, time and cost control requirements [10].

$\mathbf{C}_{4}$ : Occupational Health and Safety: According to [21], the construction industry has been one of the most dangerous industries in the world. In addition, it is well acknowledged that the construction industry has the highest accident and illness related records over any other branch or industry sector. With that in mind, many thinkers have considered safety in the construction industry as a priority in the research area. Similarly, [22] argued that around the world, health and safety in the construction industry is a grave concern.

$\mathbf{C}_{5}$ : Management Capability: The contractor must demonstrate that it is capable of planning, organizing and controlling a project. [23] reported that 8 out of 14 projects failed because of lack of managerial experience

and technical staff. Many researchers have considered management as one of the most important factors in the company's life cycle.

C6 : Reputation: [24] stated that it is important for a contractor to improve his/her reputation. This factor is usually highly prioritized over others factors, as it also indicates the capability of a contractor to complete a task with the best quality and the lowest cost [25].

$\mathbf{C}_{7}$ : Experience in similar project: Contractor experience entails the type of projects completed in respect to location, nature, size, scope, local and national experience, to determine whether or not it has handled jobs of similar nature and scope. Also it demonstrates a contractor's ability to allocate and spread its resources in an effective manner [26].

\section{Step 3: Establishing hierarchical structure}

After determining the criteria, the hierarchical structure was set up. The hierarchical structure for ranking the decision criteria consists of three levels. Level A, the target level, demonstrates the final objective of the whole hierarchical structure, which is ranking the decision criteria for Federal Universities in Nigeria. Level B contains the measurement criteria that will be rank by the AHP. Level $\mathrm{C}$ contains the alternatives or companies which are going to be measured and prioritized based on their performance. The research only consider level A and level B of the hierarchical structure. The hierarchical structure is sketched in Figure 2.

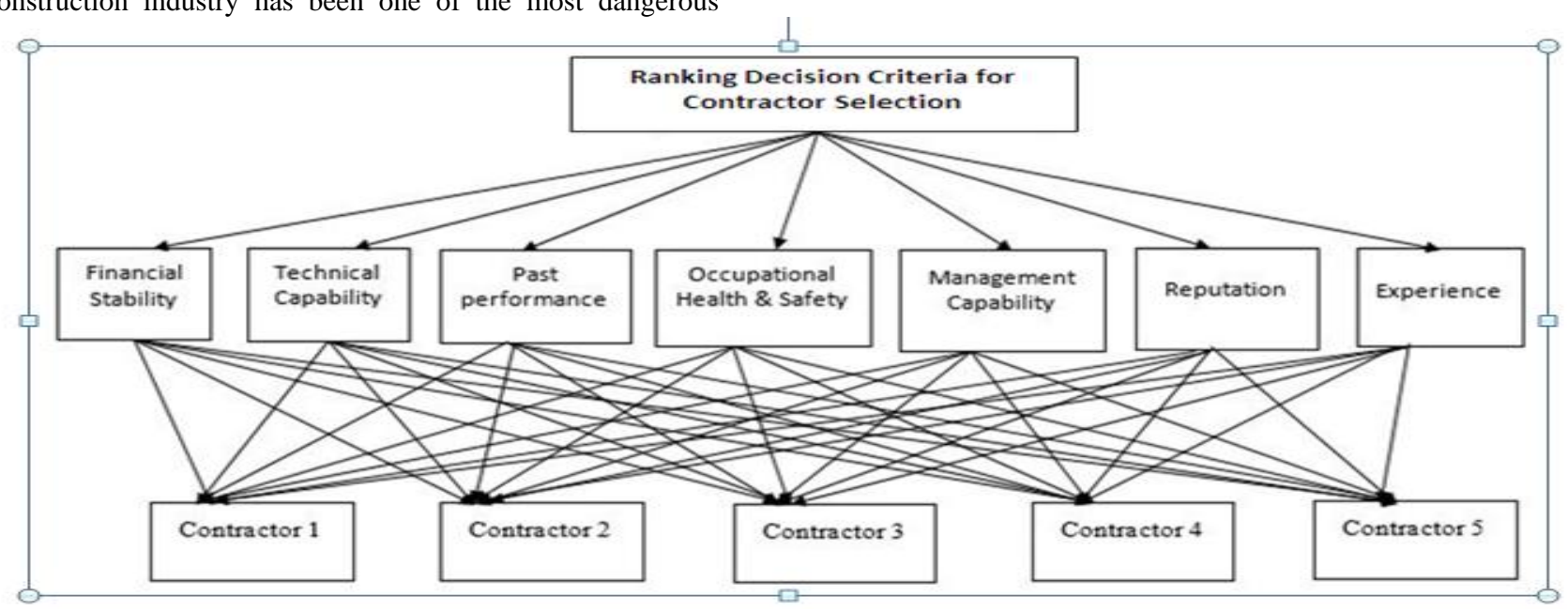

Figure 2: AHP structure

Step 4: Construct the pair-wise comparison

The definition of the priority of each criterion is obtained by conducting a questionnaire survey. In administering the questionnaires, respondents were asked to rate the level of importance of a list of main criteria used by clients in the selection of contractors in Federal Universities in Nigeria. The 
ratings were based on a 9-point Saaty AHP scale as shown in Table 3.

Table 3. Saaty AHP scale

\begin{tabular}{|l|c|l|}
\hline Value & Scale $\left(\mathbf{a}_{\mathbf{i j}}\right)$ & \multicolumn{1}{c|}{ Definition } \\
\hline Equally Important & 1 & i and $\mathrm{j}$ are equally important \\
\hline Weakly Important & 2 & i is weakly important than $\mathrm{j}$ \\
\cline { 2 - 2 } & 3 & \\
\hline Fairly Important & 4 & \multirow{2}{*}{$\mathrm{i}$ is fairly important than $\mathrm{j}$} \\
\cline { 2 - 2 } & 5 & \\
\hline Strongly Important & 6 & \multirow{2}{*}{ i is strongly important than $\mathrm{j}$} \\
\cline { 2 - 3 } & 7 & \\
\hline $\begin{array}{l}\text { Absolutely } \\
\text { Important }\end{array}$ & 8 & \multirow{2}{*}{$\mathrm{i}$ is absolutely important than } \\
\hline
\end{tabular}

All of the questions concerning the weighting are collected from the questionnaire survey. The judgments are entered using the fundamental scale for pairwise comparisons. To elicit pairwise comparisons performed at a given time, a matrix A is created. Pairwise comparison is used, because only two elements are involved in the comparison at a time as shown in equation (1).

$A=\left[\begin{array}{ccc}\mathrm{a}_{i j} & \cdots & \mathrm{a}_{i n} \\ \vdots & \ddots & \vdots \\ \mathrm{a}_{n i} & \cdots & \mathrm{a}_{n n}\end{array}\right]$

where $\mathrm{a}_{i j}=1: \forall i=j ; \mathrm{a}_{j i}=\frac{1}{\mathrm{a}_{i j}}: \forall i \neq j, \mathrm{a}_{i j}$ is the evaluation between criterion $i$ and criterion $j$ of $e^{\text {th }}$ expert

Step 5: Calculate and construct the normalized matrix The normalized matrix is then calculated by adding together each column as shown in Table 4.

Table 4. Normalized matrix showing the Sum Column

\begin{tabular}{|l|c|c|c|c|c|c|c|}
\hline Criterion & $\mathrm{Cl}$ & $\mathrm{C} 2$ & $\mathrm{C} 3$ & $\mathrm{C} 4$ & $\mathrm{C} 5$ & $\mathrm{C} 6$ & $\mathrm{C} 7$ \\
\hline $\mathrm{C} 1$ & 1 & $\mathrm{a}_{12}$ & $\mathrm{a}_{13}$ & $\mathrm{a}_{14}$ & $\mathrm{a}_{15}$ & $\mathrm{a}_{16}$ & $\mathrm{a}_{17}$ \\
\hline $\mathrm{C} 2$ & $1 / \mathrm{a}_{12}$ & 1 & $\mathrm{a}_{23}$ & $\mathrm{a}_{24}$ & $\mathrm{a}_{25}$ & $\mathrm{a}_{26}$ & $\mathrm{a}_{27}$ \\
\hline $\mathrm{C} 3$ & $1 / \mathrm{a}_{13}$ & $1 / \mathrm{a}_{24}$ & 1 & $\mathrm{a}_{34}$ & $\mathrm{a}_{35}$ & $\mathrm{a}_{36}$ & $\mathrm{a}_{37}$ \\
\hline $\mathrm{C} 4$ & $1 / \mathrm{a}_{14}$ & $1 / \mathrm{a}_{24}$ & $1 / \mathrm{a}_{34}$ & 1 & $\mathrm{a}_{44}$ & $\mathrm{a}_{45}$ & $\mathrm{a}_{47}$ \\
\hline $\mathrm{C} 5$ & $1 / \mathrm{a}_{15}$ & $1 / \mathrm{a}_{25}$ & $1 / \mathrm{a}_{35}$ & $1 / \mathrm{a}_{45}$ & 1 & $\mathrm{a}_{56}$ & $\mathrm{a}_{57}$ \\
\hline $\mathrm{C} 6$ & $1 / \mathrm{a}_{15}$ & $1 / \mathrm{a}_{25}$ & $1 / \mathrm{a}_{35}$ & $1 / \mathrm{a}_{45}$ & $1 / \mathrm{a}_{55}$ & 1 & $\mathrm{a}_{57}$ \\
\hline $\mathrm{C} 7$ & $1 / \mathrm{a}_{17}$ & $1 / \mathrm{a}_{27}$ & $1 / \mathrm{a}_{37}$ & $1 / \mathrm{a}_{47}$ & $1 / \mathrm{a}_{57}$ & $1 / \mathrm{a}_{57}$ & 1 \\
\hline $\begin{array}{l}\text { Sum } \\
\text { Column }\end{array}$ & $\mathrm{A}$ & $\mathrm{B}$ & $\mathrm{C}$ & $\mathrm{D}$ & $\mathrm{E}$ & $\mathrm{F}$ & $\mathrm{C}$ \\
\hline
\end{tabular}

To get the normalized relative weight, each element of the matrix will be divided by the sum of its column (i.e. ${ }^{a j} / A$ )

\section{Step 6: Obtained the normalized Eigen vector/Deriving Priorities (Weights) for the Criteria}

The normalized principal eigen vector can be obtained by averaging across the rows. The normalized principal eigen vector is also called priority vector. Equation (2) shows the priority vector/ weight.
Table 5. Priority vector/weight

\begin{tabular}{|c|c|c|}
\hline Criterion & & $\begin{array}{c}\text { Priority } \\
\text { vector/Normalized } \\
\text { Eigen vector }\end{array}$ \\
\hline $\mathrm{C} 1$ & $(\mathrm{C} 1+\mathrm{C} 2+\ldots . .+\mathrm{C} 7) / 7$ & $\mathbf{M}$ \\
\hline $\mathrm{C} 2$ & $(\mathrm{C} 1+\mathrm{C} 2+\ldots . .+\mathrm{C} 7) / 7$ & $\mathbf{N}$ \\
\hline $\mathrm{C} 3$ & $(\mathrm{C} 1+\mathrm{C} 2+\ldots .+\mathrm{C} 7) / 7$ & $\mathbf{O}$ \\
\hline $\mathrm{C} 4$ & $(\mathrm{C} 1+\mathrm{C} 2+\ldots .+\mathrm{C} 7) / 7$ & $\mathbf{P}$ \\
\hline $\mathrm{C} 5$ & $(\mathrm{C} 1+\mathrm{C} 2+\ldots .+\mathrm{C} 7) / 7$ & $\mathbf{Q}$ \\
\hline C6 & $(\mathrm{C} 1+\mathrm{C} 2+\ldots . .+\mathrm{C} 7) / 7$ & $\mathbf{R}$ \\
\hline $\mathrm{C} 7$ & $(\mathrm{C} 1+\mathrm{C} 2+\ldots . .+\mathrm{C} 7) / 7$ & $\mathbf{S}$ \\
\hline
\end{tabular}

The priority vector/weight is then shown in a single matrix as:

$$
\mathrm{W}=\left[\begin{array}{l}
W_{1} \\
W_{2} \\
W_{3} \\
W_{4} \\
W_{5} \\
W_{6} \\
W_{7}
\end{array}\right]
$$

\section{Step 7: Check for Consistency Ratio (CR)}

Once judgments have been entered, it is necessary to check that they are consistent. Some inconsistency is expected and allowed in AHP analysis. Since the numeric values are derived from the subjective preferences of individuals, it is impossible to avoid some inconsistencies in the final matrix of judgments [27]. The question is how much inconsistency is acceptable.

[27] proposed what is called consistency ratio (C.R), which is a comparison between Consistency Index (C.I) and Random index (R.I).

$C . R .=\frac{C . I}{R . I}$

The C.R. indicates the degree to which the pairwise judgments resemble a purely random set of pairwise comparisons. Judgments that have a C.R. lower than 0.1 are reasonable and higher than 0.1 should be revised or discarded [3]. In the case of higher inconsistency, the decision makers are advised to check for accidental mistakes and to reconsider their pairwise comparisons, until the consistency measure is below the threshold indicated.

[27] gave a measure of consistency, called Consistency Index (C.I.) as deviation or degree of consistency using equation (4):

$$
\text { C.I. }=\frac{\lambda_{\max }-n}{n-1}
$$

where $\mathrm{n}$ is the number of rows in the decision matrix and $\lambda_{\text {max }}$ is the largest eigenvalue of the comparison matrix.

To calculate the largest eigenvalue of the comparison matrix $\left(\lambda_{\max }\right)$, the row average is multiplied by the column total i.e. (row average $\mathrm{C} 1 \mathrm{X}$ column total $\mathrm{C} 1$ ), and then the sum total was calculated.

A random matrix is one where the judgments have been entered randomly and therefore it is expected to be highly 
inconsistent. The average random consistency index (R.I) of sample size 10 is shown in the Table 6 below:

Table 6. Random consistency index (R.I)

\begin{tabular}{|l|l|l|l|l|l|l|l|l|l|l|}
\hline n & 1 & 2 & 3 & 4 & 5 & 6 & 7 & 8 & 9 & 10 \\
\hline R.I & 0 & 0 & 0.58 & 0.9 & 1.12 & 1.24 & 1.32 & 1.41 & 1.45 & 1.49 \\
\hline
\end{tabular}

Step 7: Rank the criteria in order of priority

When the inconsistency is reduced to an acceptable degree, the criteria will be rank according to its respective priority

\section{RESULTS AND DISCUSSION}

Table 7. Pair-wise Comparison table for decision maker 1.

\begin{tabular}{|c|c|c|c|c|c|c|c|}
\hline \multirow{3}{*}{ Pairwise Comparison Matrix } & \multicolumn{6}{|c|}{ Calculating the Pair wise comparison } & \\
\hline & & & & & & & \\
\hline & Financial St: & Inical C & Perfor & upa: & lageme & utation & Experience \\
\hline Financial Stability & 1 & 1 & 1 & 7 & 1 & 1 & 1 \\
\hline Technical Capability & 1 & 1 & 7 & 7 & 1 & 1 & 1 \\
\hline Past Performance & 1 & $1 / 7$ & 1 & 7 & 1 & 1 & 1 \\
\hline Occupational Healt and Safety & $1 / 7$ & $1 / 7$ & $1 / 7$ & 1 & $1 / 7$ & $1 / 7$ & $1 / 7$ \\
\hline Management Capability & 1 & 1 & 1 & 7 & 1 & 1 & 1 \\
\hline Reputation & 1 & 1 & 1 & 7 & 1 & 1 & 1 \\
\hline Experience & 1 & 1 & 1 & 7 & 1 & 1 & 1 \\
\hline
\end{tabular}

Column totals

6.1429

5.2857

12.1429

43.0000

$6.1429 \quad 6.1429$

\subsection{Calculation of the Normalized Weight}

Then the normalized weight is then calculated by dividing the element in each cell by its respective column total:

Table 8. Division of each element in a cell by its column total

\begin{tabular}{|c|c|c|c|c|c|c|c|}
\hline \multicolumn{8}{|c|}{ Cw (Normalised) } \\
\hline 1 & 0.162790698 & 0.189189189 & 0.082352941 & 0.162790698 & 0.162790698 & 0.162790698 & 0.162790698 \\
\hline 2 & 0.162790698 & 0.189189189 & 0.576470588 & 0.162790698 & 0.162790698 & 0.162790698 & 0.162790698 \\
\hline 3 & 0.162790698 & 0.027027027 & 0.082352941 & 0.162790698 & 0.162790698 & 0.162790698 & 0.162790698 \\
\hline 4 & 0.023255814 & 0.027027027 & 0.011764706 & 0.023255814 & 0.023255814 & 0.023255814 & 0.023255814 \\
\hline 5 & 0.162790698 & 0.189189189 & 0.082352941 & 0.162790698 & 0.162790698 & 0.162790698 & 0.162790698 \\
\hline 6 & 0.162790698 & 0.189189189 & 0.082352941 & 0.162790698 & 0.162790698 & 0.162790698 & 0.162790698 \\
\hline 7 & 0.162790698 & 0.189189189 & 0.082352941 & 0.162790698 & 0.162790698 & 0.162790698 & 0.162790698 \\
\hline
\end{tabular}

N.B $\rightarrow$ The summation of the entire column must be equal to

\subsection{Checking the Consistency Ratio (CR)}

The formula for calculating the consistency ratio as stated in the research methodology is given by equation (4). The largest eigenvalue of the comparison matrix $\left(\lambda_{\max }\right)$ was calculated in table 10: 
Table 9. largest eigenvalue of the comparison matrix $\left(\lambda_{\max }\right)$ Calculation

\begin{tabular}{|ccc|}
\hline \multicolumn{3}{|c|}{ Calculation of $\lambda_{\text {max }}$} \\
\hline $\begin{array}{c}\text { Row } \\
\text { Average }\end{array}$ & Column Total & $\begin{array}{c}\text { Row Ave * } \\
\text { Column Total }\end{array}$ \\
\hline 0.155 & 6.1429 & 0.9521495 \\
\hline 0.226 & 5.2857 & 1.1945682 \\
\hline 0.132 & 12.1429 & 1.6028628 \\
\hline 0.022 & 43 & 0.946 \\
\hline 0.155 & 6.1429 & 0.9521495 \\
\hline 0.155 & 6.1429 & 0.9521495 \\
\hline 0.155 & 6.1429 & 0.9521495 \\
\hline & SUM TOTAL $\left(\lambda_{\max }\right)=$ & $\mathbf{7 . 5 5 2 0 2 9}$ \\
\hline
\end{tabular}

Then the Consistency Index is calculated using the formula:

C.I $=\frac{\lambda_{\max }-1}{n-1}=\frac{7.552029-1}{7-1}=0.925338166$

Thereafter the consistency ratio is calculated as R.I $=1.32$

$C . R=C . I / R . I=\frac{0.925338166}{1.32}=0.701013762<10 \%$.

Since the CR is less than $10 \%$, therefore we say the result is accepted.

\subsection{Ranking of the Criteria}

The ranking of the criteria in order of prioritization with their respective weight is shown in the Table 10:

Table 10. Vector weight for each criterion

\begin{tabular}{|c|lcc|}
\hline Criterion & Criteria & $\begin{array}{c}\text { Weight } \\
\text { Values }\end{array}$ & Ranking \\
\hline $\mathrm{C}_{1}$ & Technical Capability & $\mathbf{0 . 1 6 1 7 7}$ & 1 \\
\hline $\mathrm{C}_{2}$ & Management Capability & $\mathbf{0 . 1 5 1 8 9}$ & 2 \\
\hline $\mathrm{C}_{3}$ & Past Performance & $\mathbf{0 . 1 4 1 0 8}$ & 3 \\
\hline $\mathrm{C}_{4}$ & Financial Stability & $\mathbf{0 . 1 3 7 3 6}$ & 4 \\
\hline $\mathrm{C}_{5}$ & Experience & 0.134765 & 5 \\
\hline $\mathrm{C}_{6}$ & Reputation & $\mathbf{0 . 1 2 9 5 7}$ & 6 \\
\hline $\mathrm{C}_{7}$ & Occupational Health & & 7 \\
& and Safety & 0.11446 & \\
\hline
\end{tabular}

From the table 10, it can be seen that Technical Capability has the highest weight and it is ranked first, this criterion is perceived to be highly significant by the respondent followed by management capability and up to the criterion with the least weight; Occupation Health and safety. This ranking shows the level at which each criterion is important than the other. Figure 3 shows the graph of the decision criteria in order of their priority.

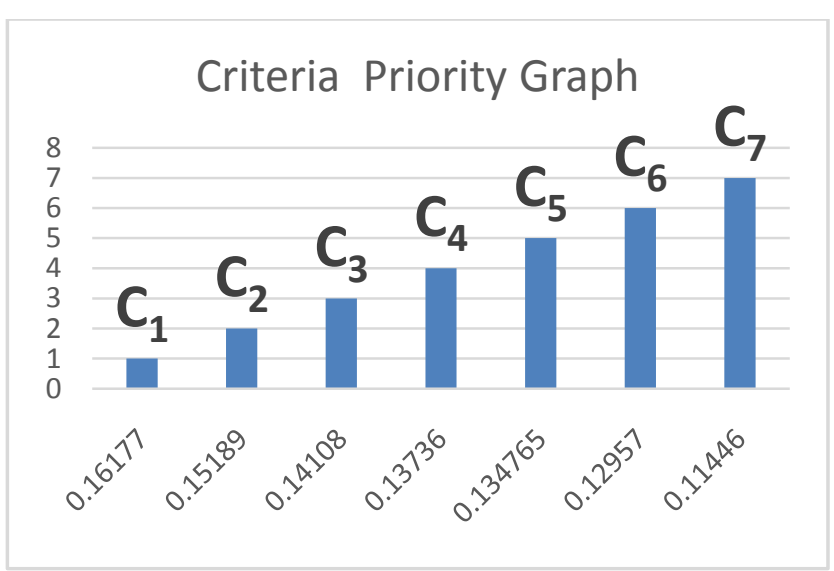

Figure 3: Graph showing criteria in order of priority

\section{CONCLUSION}

The research identified and assessed the existing contractors' decision criteria and then rank the decision criteria used for selecting contractor in Federal Universities in Nigeria with the aim of providing information that could enhance contractor's selection in construction project. Data were collected with the aid of structured questionnaires. 60 questionnaires were distributed to construction professionals/ staff of which 55 responses were returned and 50 used for analysis. Information gathered includes the major contractors' prequalification criteria. The collected data were analyzed and rank in order of priority using the AHP interface in Microsoft Excel. Here, the usage of AHP weights makes the application more realistic and reliable. The results showed that technical capability of contractors ranked the most important of the existing prequalification criterion followed by management capability among others.

Further research will be based on combining Analytic Hierarchy Process (AHP) with Fuzzy Logic for contractor selection in Nigeria since fuzzy logic has some advantages within uncertain, imprecise and vague contexts than AHP and other MCDM methods; it is similar to human judgments. It can take into account quantitative and qualitative data in the multi-attribute decision making problems.

\section{REFERENCES}

[1] Lai, K.K., Liu, S.L., Wang, S. (2007). Bid Mark-up Selection Models by use of Multiple Criteria. Transmission Engineering Management, IEEE, vol. 42(2), pg. 155-201.

[2] Olatunji O. A. (2006). Value or cost: Towards a Proficient Contractor Selection Process for Construction Works in Developing Countries - Nigeria. Proceedings of the International Conference in the Built Environment in the 21st Century. University of Technology, Marn Shah Alam, Selangor, 329-340.

[3] Saaty, T.L. (1980). The Analytic Hierarchy Process. McGraw-Hill, New York, USA.

[4] Public Procurement Act (2007), Procurement Procedures Manual for Public Procurement in Nigeria, Bureau of Public Procurement, Abuja, FCT, Nigeria.

[5] El-Sawah, H. M and Mokhtar (2000), Analysis of Bid Evaluation Model According to Egyptian Law89/1998 and International Practices, Engineering Research Journal Helwen University, Vol 71, pg1-17. 
[6] Skitmore, M. (1999). Client and Consultant Perspectives of Prequalification Criteria. Term in Construction Management. Retrieved from: http://en.wikipedia.org/wik,

[7] Palaneeswaran, E. and M. Kumaraswamy, (2001). Recent advances and proposed improvements in contractor prequalification methodologies. Build. Environ., 36:73-87.

[8] Topcu, Y.I. (2004). A decision model proposal for construction contractor selection in Turkey. Building Environ., 39: 469-481.

[9] Arazi I., Mahmoud S. and Mohamad A. A. (2011). Decision Criteria for Selecting Main Contractors in Malaysia. Research Journal of Applied Sciences, Engineering and Technology 3(12): 1358-1365, ISSN: 2040-7467.

[10] Nieto-Morote A., and Ruz-Vila F., (2011). A fuzzy AHP multi-criteria decision making approach applied to combined cooling, heating and power production systems. International Journal of Information Technology \& Decision Making, Vol. 10, No. 3 (2011) 497-517. doi: 10.1142/S0219622011004427.

[11] Puri Dwarika and Tiwari S., (2014), "Evaluating The Criteria for Contractors' Selection and Bid Evaluation ": International Journal of Engineering Science Invention ISSN (Online): 2319 - 6734, ISSN (Print): 2319 - 6726 www.ijesi.org Volume 3 Issue 7 || July 2014 || PP.44-48

[12] Elsayah, O., Naren, G., Binsheng Z. (2013). Ranking of the Main Criteria for Contractor Selection Procedures on Major Construction Projects in Libya Using the Delphi Method. World Academy of Science, Engineering and Technology, vol. 7, pg. 12.

[13] Salama M., Abd El Aziz H., El Sawah H. and El Samadony A. (2006). Investigating the criteria for contractors' selection and bid evaluation in Egypt. In: Boyd, D (Ed) Procs 22nd Annual ARCOM Conference, 4-6 September 2006, Birmingham, UK, Association of Researchers in Construction Management, 531-540.

[14] Olatunji O.A., Aje,O.I, and Odugboye F. (2007); Evaluating Health and Safety performance of Nigeria construction site. CIB world building congress vol.051, pp 1187.

[15] [15] Ogunsemi, D. R. and Aje, I. O (2006a). The Impact of Contractors Prequalification on Construction Project Delivery in Nigeria. Proceedings of the International in the Built Environment in the 21st Century. University of Technology, Marn Shah Alam, Selangor. 111-120.

[16] Ajayi, O.M. (2010). Multi-criteria decision making model for contractor selection in instruction projects in
Nigeria. In Layer, S. Leirinyer R and Hughes, W (EdS) Procs West Africa Built Environment Research (WABER) conference, 27 -28 July 2010, Africa, Ghana pp. 423-433.

[17] Nkanta S.D., Akpanebu I.J. and Udoka I. S. (2017). Determinants of Contractors' PreQualification Criteria in a Recessed Economy Nigeria. International Journal of Advanced Studies in Business Strategies and Management Vol. 5, pg 1.

[18] Isik, Z., Arditi, D., Dikmen, I. and Birgonul, M. T., (2009). Impact of corporate strengths/weaknesses on project management competencies. 27(2), pp. 629-637.

[19] Watt, D., Kayis, B. and Willey, K. (2009). Identifying key factors in the evaluation of tenders for projects and services. International Journal of Project Management, 27(3), pp. 250- 260.

[20] Padhi, S. S. and Mohapatra, P. K. (2009). Centralized construction contractor selection considering past performance of contractors: a case of India. Operational Research, 9(2), pp. 199-224.

[21] Hoonakker, P., Loushine, T., Carayon, P. \& Kallman, J., 2005. The effect of safety initiatives on safety performance: A longitudinal study. Elsavier, 1(36), pp. 461-469.

[22] Tam, M. C., Zeng, S. X. and Deng, Z. M. (2008). Towards occupational health and safety system in the construction industry of China. Safety Scince, 46(8), pp. 1155-1168.

[23] Russell, J. S. (1991). Contractor Failure: Analysis. Journal of Performance of Constructed Facilities, ASCE, 5(3), 163-180.

[24] Aje, O., Odusami, K. T. and Ogunsemi, D. (2009). The impact of contractors' management capability of construction projects in Nigeria. Journal of Financial Management of Property and Construction, 14(2), pp. 171-187.

[25] Kadefors, A., Bjorlingson, E. and Karlsoon, A., (2007). Procuring service innovations: Contractor selection for partnering projects. International Journal of Project Management, 25(4), p. 375-385.

[26] Ramani, J. (2000). Reducing the Bias in Contractor Prequalification Using Data Envelopment Analysis (DEA). M.Sc. Project, Department of Civil Engineering, University of Toronto, Ontario.

[27] Saaty, Thomas L. (2012). Decision Making for Leaders: The Analytic Hierarchy Process for Decisions in a Complex World. Fifth Edition ed. Pittsburgh: RWS. 